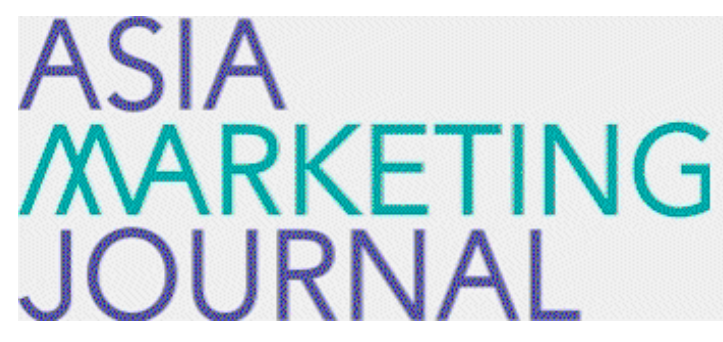

ASIA MARKETING JOURNAL

Volume 2 | Issue 4

Article 5

$12-1-2000$

\title{
CIP ( Corporate Identity Program ) 에 의한 상호변경이 기업의 이익 \\ 흐름에 미치는 영향에 관한 연구
}

Tae Hee Lee

Chan Su Park

Follow this and additional works at: https://amj.kma.re.kr/journal

Part of the Marketing Commons

\section{Recommended Citation}

Lee, Tae Hee and Park, Chan Su (2000) "CIP ( Corporate Identity Program ) 에 의한 상호변경이 기업의 이 익흐름에 미치는 영향에 관한 연 구," Asia Marketing Journal: Vol. 2 : Iss. 4 , Article 5.

Available at: https://doi.org/10.53728/2765-6500.1053

This Article is brought to you for free and open access by Asia Marketing Journal. It has been accepted for inclusion in Asia Marketing Journal by an authorized editor of Asia Marketing Journal. 


\title{
CIP (Corporate Identity Program)에 의한 상호변경이 기업의 이익흐름에 미치는 영향에 관한 연구*
}

\section{Effects of Corporate Identity Program on the Profit Performance of the Firm}

\author{
이태희 (국민대학교 경영학부 부교수) \\ thlee@kookmin.ac.kr \\ 박찬수 (고려대학교 경영대학 부교수) \\ chansu@korea.ac.kr
}

\begin{abstract}
본 연구에서는 1990 년대에 들어와서 국내의 많은 대기업들이 실시한 Corporate Identity Program (CIP)으로 인한 기업 이름의 변경이 기업의 이익 흐름에 미치는 영향을 event study method를 이용하여 실증적으로 분석하였다. 1992년부터 1996년 사이에 CIP의 일환으로 기 업 이름을 모기업 또는 그륩의 명칭과 동일하게 변경시킨 31 개 기업들을 대상으로 event study를 실시한 결과는 다음과 같다: 첫째, 평균적으로, $\mathrm{CIP}$ 에 의한 상호 변경은 그 기업의 주식 가격에 긍정적인 영향을 미치지 않았다. 둘째, 업중별로 분석해보면, 비금응기관의 상 호변경이 금융기관의 상호변경보다 주식 가격에 더 긍정적인 영향을 미첬으며, 소비재률 생 산하는 기업들의 상호변경이 산업재를 생산하는 기업들의 상호변경보다 더 긍정적인 영향을 미쳤다.
\end{abstract}

· 논문접수: 01.04 게재확정 : 01.05 


\section{1. 서론}

1992년부터 1996년 사이에 우리나라의 약 40개 상장 기업들이 Corporate Identity Program (이하 CIP라 약칭함)에 따라서 계열사들의 商號를 통일하거나 (예: 한신중권 - 동원중권), 그룹 명을 새로 제정하고 계열사들의 상호를 여기에 맞추어서 변경하였다 (예: 력키화확 $\rightarrow$ LG화학). 이렇게 짧은 기간동안에 이렇게 많은 기업들이 CIP에 인한 상호 변경을 실시한 것은 국내외를 막론하고 그 유례를 찾기 어려울 것이다. 예를 들어, 1980년부터 1990년까지 11 년 동안 우리나라에서 CIP로 인하여 상호를 변경한 기업들의 수는 불과 10 개에 불과하다 는 사실에 비추어 보면, 이 기간 동안에 일어난 CIP의 강도를 짐작할 수 있다.

$\mathrm{CIP}$ 를 실시하는 데에는 일반적으로 사내외의 전문가들이 동원되어 세밀한 검토를 거치게 되므로 많은 비용과 시간이 소요된다. 또, 새로운 Corporate Identity (이하 CI라 약칭함)가 일 단 공표된 후에도 이를 고지하기 위한 광고 비용과 간판에서부터 직원들의 명합에 이르기까 지 교체비용 둥이 적지 않게 들어가는 것이 일반적이다. 예를 들어, 호남정유가 LG칼텍스 정유로 상호를 변경하는 데에는 모두 50 억원 가량의 비용이 소요될 것으로 알려졌다 (한국 경제신문 1996. 5. 29.). 미국의 경우, AT\&T에서 분리된 Lucent Technologies는 CIP에 총 1 억 달러 이상을 지출한 것으로 추정되었다 (Briones 1998).

더욱이 상호 변경에는 상당한 위헙이 수반된다. 기존의 상호로 상당 기간 동안 사업을 영위하면서 구축해온 높은 인지도와 유리한 이미지와 같은 브랜드 자산의 상당 부분을 상호 변경으로 상실할 가능성이 높다. 또, 지금까지 각각 상이한 상호를 갖고 있던 계열사들의 상호를 하나로 통일하면, 만일 어느 한 계열사가 사희적인 물의를 일으키는 경우 다른 모든 계열사들에게 나뽄 파급효과를 미치게 될 수도 있다.

이러한 비용과 위헙에도 불구하고 많은 기업들이 CIP률 실시하는 것은 궁극적으로 그렇 게 하는 것이 하지 않는 경우보다 기업의 미래 이익올 높여 줄 수 있다는 확신이 있기 때문 이라고 볼 수 있다. 상호 변경이 기업의 미래 이익을 높여 줄 수 있는 경우에는 다음의 두 가지가 있을 수 있다 (Horsky and Swyngedouw 1987).

첫째, 기업 이름 자체가 고객에게 효용을 발생시키는 속성이라면, 체계적인 CIP를 통하여 채택된 기업 이름은 종전의 이름을 사용하는 경우보다 고객에게 더 큰 효용을 제공하게 될 것이므로 (예: 한신증권 $\rightarrow$ 동원중권), 자사 제품에 대한 수요 함수를 바깥쪽으로 이동시켜 서 종전보다 더 높은 가격을 받을 수 있게 하거나, 아니면 가격을 그대로 두는 경우에는 더 높은 판매량을 올릴 수 있게 해 줄 것이다. 부수적으로, 계열 기업들의 상호를 하나로 통일 시키는 경우 (예: LG 그룹) 계열 기업별로 집행하던 기업 이미지 광고률 그륩 이미지 광고 로 대체할 수 있으므로 비용 절감 효과도 거둘 수 있다. 이러한 수요 중대 또는 비용 절감 효과를 편의상 앞으로 수요증대/비용절감 효과라고 부르기로 한다.

둘째, 기업 이름 자체는 고객에게 아무런 효용을 발생시키지 않는다 하더라도, 단지 기업 이름을 바꾼다는 것 자체가 기업 내외의 이해관계자들에게 긍정적인 signal로서 작용하여 기 업의 미래 가치률 높일 수 있다. 족, 기업 이름의 변경은 그 기업이 과거와 단절하고, 곧바 로 구조 조정과 같은 바람직한 변화를 시행할 것이라는 암묵적인 약속을 사전에 하는 것이 라고 불 수 있다. 이러한 signal이 신뢰성이 높다면, 기업의 임직원들에게 동기 유발 효과를 가져올 수 있고, 투자자들에게도 호의적인 반웅을 얻을 수 있을 것이다. 이러한 효과를 편 의상 앞으로 signaling 효과라고 부르기로 한다. 
CIP에 따른 상호 변경이 잠재적으로 가져울 수 있는 위와 같은 미래 이익 중대 효과에도 불구하고, 상호변경에 수반되는 높은 비용과 위헙을 감안할 때, 과연 CIP가 기업의 미래 가 치를 중가시키는가 하는 의문이 중요한 이슈로 대두된다. 본 연구는 실중적인 분석을 통하 여 이러한 의문에 대한 해답을 제시하는데 그 목적을 두고 있다.

본 논문은 다음과 같이 구성되어 있다. 2절에서는 상호 변경의 효과률 분석한 기존의 연 구 결과듈을 고찰하고, 3절에서는 연구 가설들을 설정하며, 4절에서는 분석 대상 기업들을 선 정하고, event date를 설정한 다음, 실중 분석 결과를 논의한다. 5 절에서는 연구 결과를 요약 하고 향후 연구 과제를 제시한다.

\section{2. 관련 문헌 고찰}

CIP로 인한 상호 변경이 기업의 이익에 미치는 영향을 분석한 논문은 국내외를 통틀어 전무하며, CIP에 의한 상호 변경을 다른 사유에 의한 상호변경과 합쳐서 분석한 논문들도 불과 몇 편에 블과하다 (예: Horsky and Swyngedouw 1987; 송영균 1991). 이들은 재무론에서 개발된 event study method (Brown and Warner 1980, 1985)를 사용하였다는 공통점을 갖고 있지 만, 서로 뷸일치되는 실중 분석 결과를 제시하고 있다.

상호 변경이 기업의 이익을 중대시컸는지를 살펴보기 위해서는 상호 변경 전과 후의 이익 을 비교해야 할 것으로 생각하기 섭다. 그러나, 이를 위해서는 기업의 이익에 영향을 미치 는 여러 가지 사전들울 퉁제하는 것이 필요한데, 이는 실제로 불가능에 가깝다. 따라서, 기 존의 연구들은 상호 변경 전후의 이익을 직접 비교하는 대신에 상호 변경 계흭이 처음으로 시장에 알려진 당일 주가의 중감을 살펴보는 event study method를 이용하고 있다.

Event study method의 이론적 배경은 재무론에 근거하고 있다. 이론적으로 볼 때, 주식의 가격은 앞으로 기대되는 현금 흐름의 현재 가치와 동일하다고 할 수 있다. 재무론에서 개 발된 효율적 시장 가설에 따르면 (Fama 1970), 주식의 가격은 현재 나와있는 모든 정보를 반 영하고 있다고 한다. 그러므로, 투자자들이 예상하지 못한 사건이 일어나는 경우에만 주식 의 가격이 변화하며, 그 변화의 크기는 기업의 미래 기대 현금 흐륨의 변화의 불편추정치가 된다. 즉, 어떤 사건이 기업의 가치에 영향을 주었는지를 분석하려면, 주식 가격의 초과 수 익률 (abnormal return)을 측정하면 된다는 것이다.'

Horsky and Swyngedouw (1987)는 1981년부터 1985년 사이에 상호를 변경한 58개의 미국 상 장 기업들을 대상으로 event study를 실시한 결과 event date의 평균 초과 수익률이 $0.61 \%$ 에 달하며 퉁계적으로 유의하다는 것을 발견하였다. 또한 그들은 cross-sectional 회귀분석을 통 하여, 이러한 초과 수익률이 산업재률 생산하는 기업들에서 소비재를 생산하는 기업들에서 보다 높게 나타나고, 금융기관듈에서 비금융기관들에서보다 낮게 나타난다는 사실을 발견하 였다. 그러나, 이들의 연구에서는 CIP에 의한 상호 변경은 물론 인수, 합병 둥 다른 사유에 의한 상호 변경까지도 모두 분석 대상에 포함시켰기 매문에, 본 연구의 목적과는 다소 거리 가 있다. 또, 얼마나 많은 기업들이 CIP에 의한 상호 변경을 하였는지, 또 그러한 기업들의 평균 초과 수익률이 유의하였는지률 추정하는 것이 불가능하다.

${ }^{1}$ Event study method및 초과수익률에 대한 자세한 설명은 Horsky and Swyngedouw (1987, pp. 322-324)에 나와 있으므로, 본 논문에서는 지면 관계상 생략함. 
1980 년부터 1990년까지 상호를 변경한 74 개의 국내 기업들을 대상으로 동일한 방법을 적 용한 송영균 (1991)의 연구에서는 대상 기업들 중 CIP에 의하여 상호률 변경한 기업들의 수 가 10 개에 불과하였으며, 이들 기업의 event date에서의 평균 초과 수익률은 물론 event date \pm 3 일간의 평균 초과 수익률도 통계적으로 유의하지 못한 것으로 나타넜다. 더욱이, 74 개 대상 기업 전체의 평균 초과 수익률도 통계적으로 유의하지 못한 것으로 나타났다. 본 연 구자들은 이렇게 유의하지 못한 결과가 나오게 된 것에 대하여 다욤과 같은 두 가지 해석 을 붙일 수 있다고 생각한다. 첫째, 방법론상의 문제가 있었을 가능성이 있다. 2,3일간의 주가변동에서 정보효과를 추론하는 event study method에서는 event date의 정확성 여부가 연 구결과의 신뢰성을 좌우하는 매우 중요한 요소이다. 특히 시장이 효율적이면 효율적일수 록 예상하지 못했던 사건이 주가에 영향올 미치는 기간은 단기에 그치게 된다. 송영균의 연구에서는 event date를 설정하기 위하여 해당 기업이 證券市場紙에 상호 변경 의도를 공시 한 날짜 중에서 최초일을 기준으로 삼았다. 그러나, 본 연구자들이 상호 변경을 한 기업들 올 대상으로 조사한 바에 따르면, 상당히 많은 기업들의 경우 상호 변경 의도를 중권시장지 에 공시하기 전에 이미 여러 언론기관에서 상호 변경 의도를 보도한 것이 발견되었다. 그 러므로, 최초보도일이 최초공시일보다 앞서는 경우에는 최초보도일을 event date로 삼아야 할 것이다. 통계적으로 유의한 초과수익률을 입증한 Horsky and Swyngedouw (1987)도 Dow Jones News Service가 최초로 보도한 일자를 event date로 설정하였다. 둘째, 이러한 데이터상의 또 는 방법론상의 문제에도 불구하고, 우리나라에서는 미국과는 다른 여러 가지 사정 때문에 상호 변경이 실제로 주가에 영향을 미치지 않았을 가능성도 있다. 그러나, 이러한 해석이 힘을 얼기 위해서는 앞서 언급한 문제점올 걷어내는 것이 필요하다.

따라서, 본 연구의 일차적인 목적은 event date를 보다 정확하게 설정함으로써 우리나라 기 업들이 CIP에 따라 상호 변경을 한 것이 가져올 효과를 보다 정확하게 분석하는데 있다. 이렇게 함으로써, 사건일의 부정확한 확정에 따른 문제점을 상당 부분 해소시켜주어 주가의 움직임으로부터 CIP의 효과에 대한 보다 강력한 추론을 가눙하게 할 것이다.

\section{3. 연구 가설의 설정}

1 절에서 언급된 여러 가지 위협에도 불구하고, 기업들이 CIP를 실시하는 것은 그렇게 하 는 것이 비용을 절감하고 대외 이미지를 개선함으로써 미래이익이 중가할 것이라는 신념을 갖고 있기 때문이라고 할 수 있다. 현재의 주가가 미래이익의 현재가치롤 반영한다면(Fama 1970), 상호변경 의사가 시장에 처음 알려지는 시점에서 상호변경기업들의 주가는 양의 초 과수익률을 경험할 것이다.

<가설 1>CIP로 인한 초과수익률은 0 보다 크다.

종합금융사, 중권사, 보험사 등과 같은 금융기관들은 고객에게 유형의 제품을 판매하는 제 조기업과는 달리 고객들로부터 현금을 납입받고 원금 및 원금의 운용에서 생기는 부가가치 를 미래에 되돌려주는 영업을 수행한다. 따라서 금용기관의 성패는 신용에 달려 있다고 해 도 과언이 아니다. CIP를 통하여 계열금욤기관의 상호가 강력한 브랜드 자산을 구축한 모기 
업의 상호로 통일된다면, 고객들의 신용도는 크게 높아져 금용기관의 가치를 높일 수 있올 것이다.

이와는 반대로, 금융기관들이 구조조정기에 있을 때에는 구조조정과정의 하나로서 상호변 경을 단행하는 경우가 있으며 이때의 상호변경은 고객 또는 투자자의 위헙의 중가를 알리는 신호(signal)의 역할을 하기 때문에, 이러한 신호가 시장에 전달된다면 투자자들이 동요하게 됨으로써, 해당 금용기관의 가치는 크게 감소될 것이다.

상기한 두 가지의 시나리오는 각기 다른 방향의 주가 움직임을 예견하고 있으며 어떤 시 나리오가 더 설득력이 있는가 하는 것은 실중적인 이슈이다. 다만 두 가지 시나리오를 통해 알 수 있는 것은 금융기관의 상호변경이 다른 기업의 상호변경과는 다른 효과를 가져오리라 는 점이다.

<가설 2> 금용기관의 CIP로 인한 초과수익률은 비금용기관의 CIP로 인한 초과수익률과 같지 않다.

기업상호변경의 효과는 해당 기업의 제품을 구입하는 소비자의 특성에 따라 달라질 수 있 다. 만일 상호변경의 효과가 존재한다면 그 효과는 산업재 보다는 소비재를 생산하는 기업 에서 더 크게 나타날 수 있다. 왜냐하면 산업재는 구매자들이 제품의 품질을 비교적 객관적 으로 평가할 수 있으나, 소비재는 소비자의 주관적인 지각에 따라 품질 평가가 크게 좌우될 수 있으므로 브랜드의 영향력이 상대적으로 더 높을 것이다.

그러나, 다른 한 편으로는 상호변경으로 인한 각중 커뮤니케이션 비용이 소비재의 경우가 산업재의 경우보다 일반적으로 더 커지므로, 소비재를 매매하는 기업의 주가가 더 크게 하 락할 수 있다. 위와 같은 상반된 논리는 다음과 같은 가설의 설정을 가능하게 한다.

<가설 3> 산업재를 생산하는 기업의 CIP로 인한 초과수익률은 소비재를 생산하는 기업 의 CIP로 인한 초과수익률과 같지 않다.

상호변경으로 인해 발생하는 비용의 상당 부분은 기업규모와는 무관하게 발생한다. 예컨 대, 상호변경을 위한 시장조사비용이나 법률비용 둥은 기업규모가 크다고 비례적으로 발생 하지는 않는다. 더구나, 대기업들이 CIP률 할 경우 free publicity의 혜택을 더 많이 받을 수도 있다. 따라서 이들 기업의 주가는 상대적으로 더 높아질 것이다. 이와는 반대로 상호변경 이 기업의 구조조정을 신호하는 것이라면 기업의 규모가 클수록 구조조정이 상대적으로 어 렵거나 이에 수반되는 비용이 더 커질 것이므로, 상호변경과 기업규모와는 음의 상관관계를 가질 것이다.

<가설 4> 규모가 큰 기업의 CIP로 인한 초과수익률은 규모가 작은 기업의 CIP로 인한 초과수익률과 같지 않다.

\section{4. 실중 분석}

4.1. 표본기업의 구성 및 사건일의 결정 
본 연구는 1992년부터 1996년 사이에 CIP (Corporate Identity Program)에 의하여 상호를 모 기업 또는 그릅의 명칭과 동일하게 변경시킨 기업들을 대상으로 하고 있다. 연구의 대상을 1992년부터 1996년 사이의 기업으로 정한 이유는 다음과 같다.

본 연구에서는 event date를 보다 정확하게 설정하기 위하여 최초보도일자, 최초공시일자, 주주총회일자 중에서 빠른 날짜를 event date로 설정하였다. 여기서 최초 보도일은 PC 통신 이나 인터넷에서 제공하는 주요 일간지 기사 데이터베이스를 이용하여 찾을 수 있고, 최초 공시일과 주주 총회일은 한국중권거래소 기업내용 공시실에서 제공하는 데이터베이스를 이 용하여 찾을 수 있다. 그런데, 기사 데이터베이스의 구축 시점은 신문에 따라 상당히 차이 가 있다. 종합지들 중에는 빠르게는 1992년부터 기사를 데이터베이스화하여 제공하는 신문 도 있지만, 기업에 관한 기사가 많이 실리는 경제지들온 종합지에 비하여 데이터베이스 구 축올 늦게 시작하여 1995년 말 이후부터 기사를 데이터베이스화하여 제공한다는 문제점을 가지고 있다. 본 연구는 이러한 제약들을 감안하여 1995년말 이후부터는 한국경제신문의 기사 데이터베이스에서 최초 보도일을 찾고, 1992년부터 1995년 말까지는 중앙일보에서 제공 하는 JOINS 산업정보 데이터베이스에서 최초 보도일을 찾았다. 또한 이렇게 구한 최초 보도 일의 정확성을 검중하기 위해 다시 한국신용평가에서 제공하는 기업 정보 데이터베이스에서 찾은 쳐초 보도일과 비교하여 가장 빠른 것을 최초 보도일로 설정하였다. 또한 1997년 이 후의 경우에는 외환 위기 발생과 그 극복 과정에서 주식시장이 급격한 변동을 경험한 시기 였기 때문에, 분석 대상에서 제외하였다.

이렇게 1992년부터 1996년 사이에 CIP에 따라서 상호를 변경한 기업들을 대상으로 데이 터베이스에서 탐색한 결과 38 개 기업의 최초 보도일, 최초 공시일, 주주 총회일을 찾을 수 있었다. 그런데 상호 변경 이외의 주가에 영향을 미칠 수 있는 다른 요인들을 제거하기 위 하여, CIP 이외의 사업목적 추가, R\&D 투자계흭 공시 둥과 같은 정보를 공시한 기업 4개를 제거하였다. 또한 3 개의 기업은 주식시장에서의 주가수익률을 측정할 수 없는 관계로 표본 에서 제외하였다. 따라서 본 연구에서 이용하는 최종 표본 수는 31 개 기업을 대상으로 한 다. 이들 31 개 기업의 명단과 최초 공시 일자, 주주 충회 일자, 최초 보도 일자는 <표 $1>$ 에 나와있다. 총 31 개 기업 중에서 보도 일자가 공시 일자보다 앞서는 경우가 19개에 달합으로 써, 본 연구가 선행 연구보다 event date를 정확하게 설정하게 되었음을 알 수 있다.

<표 1> 표본 기업들의 최초공시일자, 주주총회일자 및 최초보도일자

\begin{tabular}{|l|l|c|c|c|}
\hline \multicolumn{2}{|c|}{ 기업명 } & \multirow{2}{*}{$\begin{array}{c}\text { 공시일자 } \\
\text { (월/일/연) }\end{array}$} & $\begin{array}{c}\text { 주총일자 } \\
\text { (월/일/연) }\end{array}$ & $\begin{array}{c}\text { 보도옹전 } \\
\text { (월/일/열/연) }\end{array}$ \\
\hline 백화 & 두산백화 & $2 / 6 / 96$ & $2 / 28 / 96$ & $12 / 6 / 95$ \\
한양화학 & 한화종합화학 & $2 / 17 / 94$ & $2 / 26 / 94$ & $2 / 8 / 94$ \\
한국비료공업 & 삼성정밀화학 & $10 / 10 / 94$ & $10 / 26 / 94$ & $10 / 26 / 94$ \\
경인에너지 & 한화에너지 & $2 / 7 / 94$ & $2 / 28 / 94$ & $2 / 8 / 94$ \\
려키금속 & LG금속 & $2 / 24 / 95$ & $2 / 27 / 95$ & $1 / 3 / 95$ \\
연합인슈 & 산내들인슈 & $2 / 12 / 96$ & $2 / 28 / 96$ & $2 / 29 / 96$ \\
한국종합기계 & 한화기계 & $2 / 22 / 94$ & $3 / 3 / 94$ & $2 / 8 / 94$ \\
금성사 & LG전자 & $2 / 6 / 95$ & $2 / 25 / 95$ & $1 / 3 / 95$ \\
삼미기업 & NK텔레콤 & $3 / 8 / 96$ & $3 / 22 / 96$ & $3 / 7 / 96$ \\
\hline
\end{tabular}




\begin{tabular}{|l|l|c|c|c|}
\hline 도신산업 & 신호전자통신 & $2 / 15 / 96$ & $2 / 27 / 96$ & $2 / 28 / 96$ \\
한국마벨 & 한솔전자 & $10 / 21 / 95$ & $10 / 30 / 95$ & $10 / 30 / 95$ \\
금성전선 & LG전선 & $2 / 9 / 95$ & $2 / 28 / 95$ & $1 / 3 / 95$ \\
금성산전 & LG산전 & $2 / 17 / 95$ & $2 / 17 / 95$ & $1 / 3 / 95$ \\
럭키개발 & LG건설 & $2 / 7 / 95$ & $2 / 24 / 95$ & $1 / 3 / 95$ \\
광주고속 & 금호건설 & $12 / 13 / 93$ & $12 / 13 / 93$ & $11 / 26 / 93$ \\
럭키금성상사 & LG상사 & $2 / 10 / 95$ & $2 / 28 / 95$ & $1 / 3 / 95$ \\
인천투금 & 쌍용종금 & $5 / 27 / 96$ & $5 / 27 / 96$ & $4 / 4 / 96$ \\
삼희투금 & 한화종금 & $5 / 27 / 96$ & $5 / 27 / 96$ & $4 / 4 / 96$ \\
국제종합금응 & 현대종금 & $5 / 13 / 94$ & $5 / 26 / 94$ & $4 / 24 / 94$ \\
부산투금 & 엘지종금 & $1 / 24 / 94$ & $3 / 18 / 94$ & $4 / 24 / 94$ \\
전북투금 & 삼양종금 & $4 / 15 / 94$ & $5 / 19 / 94$ & $4 / 24 / 94$ \\
반도투금 & 고려종금 & $8 / 11 / 94$ & $8 / 26 / 94$ & $5 / 27 / 94$ \\
동해종금 & 한솔종금 & $10 / 21 / 95$ & $9 / 28 / 95$ & $8 / 8 / 95$ \\
력키중권 & LG중권 & $2 / 4 / 95$ & $2 / 18 / 95$ & $1 / 3 / 95$ \\
제일중권 & 한화중권 & $5 / 20 / 96$ & $5 / 25 / 96$ & $5 / 25 / 96$ \\
한신중권 & 동원중권 & $2 / 2 / 96$ & $3 / 9 / 96$ & $1 / 17 / 96$ \\
한국투자중권 & 장은중권 & $5 / 4 / 94$ & $5 / 28 / 94$ & $5 / 12 / 94$ \\
상업중권 & 일온중권 & $11 / 28 / 94$ & $12 / 13 / 94$ & $12 / 13 / 94$ \\
고려화재해상 & 쌍용화재해상 & $5 / 19 / 94$ & $5 / 26 / 94$ & $5 / 27 / 94$ \\
럭키화재 & LG화재 & $4 / 28 / 95$ & $5 / 26 / 95$ & $1 / 3 / 95$ \\
한국자동차보험 & 동부화재 & $5 / 10 / 95$ & $5 / 26 / 95$ & $5 / 26 / 95$ \\
\hline
\end{tabular}

\section{2. 변수의 정의}

본 연구에서 사용한 변수들은 다음과 같다:

CAR: CIP에 의하여 상호변경을 한 기업의 자본시장에서의 상대적 성과의 측정치로서 본 연구는 누적초과수익률(cumulative abnormal retums, CAR)을 이용하였다.

$C A R_{p t}=\sum_{t=0}^{T} \frac{1}{N} \sum_{i=1}^{N}\left[R_{i, t}-\left(\hat{\alpha}_{i}+\hat{\beta}_{i} R_{m, t}\right)\right]$

여기서

$C A R_{p t}: p$ 시점에서 $t$ 시점까지의 누적초과수익률,

$R_{i, t}: t$ 시점에서의 주식 $i$ 의 일별 수익률,

$R_{m, t}: t$ 시점에서의 시장수익률,

$N$ : 표본기업의 수,

$\hat{\alpha}_{i} \quad$ : 시장수익률이 0 일 때의 기대수익률, 즉 알파계수의 추정치,

$\hat{\beta}_{i} \quad$ : 주식 $i$ 의 베타계수의 추정치. 
$\hat{\alpha}_{i}$ 와 $\hat{\beta}_{i}$ 의 추정 기간은 event date전 321일부터 event date전 31 일까지률 사용하였다. 이것은 Horsky and Swyngedouw (1987)에서와 동일하다.

FIN: 해당 기업이 금응산업에 속하는지의 여부률 나타내는 더미 변수로서, 금융기관에는 1 을 부여하고, 나머지 기업에는 0 을 부여하였다. 표본기업이 금융업에 속하는가의 여부를 결 정하기 위하여 한국표준산업분류코드(KSIC, 2-digit level)을 이용하였다.

CONS: 해당 기업이 소비재 기업인지의 여부를 나타내는 더미 변수로서, 소비재의 구분은 한국신용평가 데이터베이스를 이용하여 '기업의 주생산품'을 검토한 후, 주생산품이 소비재 기업에는 1 을 부여하고, 산업재 기업에는 0 을 부여하였다.

SALES: 기업의 규모에 대한 대용치로서 본 연구는 선행연구에서와 마찬가지로 매출액을 사용하였다.

\section{3 분석 결과}

먼저 상호변경을 전후하여 어떠한 주가의 움직임이 있는가를 확인하기 위해 event date를 전후하여 -30 일부터 +30 일까지의 누적수익률을 $C A R_{p t}$ 를 계산한 결과가 <표 2>에 나와 있 다. event date 하루전과 당일, 즉 [-1일, 0 일]의 기간 동안의 초과누적수익률은 유의적인 수 준이 아니다. 이는 최소한 상호변경 event date 시점에서는 주식시장이 상호변경기업에 대해 호의적으로 반웅하지 않음올 의미하며 따라서 '상호변경기업은 양의 초과수익률을 경험한 다"는 첫 번째 가설은 지지되지 않는다.

<표 2>CAR $R_{p i}$ 의 퉁계량

\begin{tabular}{|l|c|c|c|}
\hline \multirow{2}{*}{} & \multicolumn{3}{|c|}{ CAR } \\
\cline { 2 - 4 } & {$[-1,0]$} & {$[-1,30]$} & {$[-1,60]$} \\
\hline 평균 & -0.00004 & 0.02357 & 0.05530 \\
\hline$t$-values & -0.007 & 0.66 & 1.02 \\
\hline$p$-values & 0.99 & 0.52 & 0.31 \\
\hline
\end{tabular}

위와 같은 결과는 Horsky and Swyngedouw (1987)의 표본기업이 같은 기간 동안에 경험한 $0.61 \%$ 의 ( $t=2.15)$ 양의 초과수익률과는 상반되는 결과이지만, 송영균(1991)의 표본이 경험한 초과수익률과는 유사한 결과이다. 이는 미국의 주식시장과는 달리 한국의 주식시장에서는 CIP로 인한 상호변경이 그리 큰 주가움직임을 야기시키지 못했음을 의미한다.

상호변경 event date 시점에서 주가가 상승하지 않았지만, 그 이후에 이로 인한 상숭이 있 을 가능성이 있다. 만일 투자자들이 상호변경에 대해 event date가 아닌 그 이후의 기간 동 안에 호의적으로 반웅한다면 비록 event date에는 주가가 상승하지 않았다 하더라도 이후에 주가가 상숭할 수 있을 것이다. 이와 같은 정보공시에 대한 투자자들의 지체된 반웅 (delayed reaction)에 대한 연구는 Bernard and Thomas(1989, 1990), Lakonishok and Vermaelen(1990) 둥에서도 확인된 바 있다. 상호변경에 대한 선행 연구들에서도 event date 이후에 누적초과 수익률이 지속적으로 중가하는 것이 확인된 바 있다. Horsky and Swyngedouw (1987)는 event date 이후 +10 일 동안 주가가 약 $2 \%$ 중가함을 보여주었으나 이에 대한 설명은 하지 않았다. 송영균(1991)은 보다 적극적으로 “대단한 상호변경”표본의 경우 공시전후 60 일간 무려 $14 \%$ 
의 초과수익률이 나타넜고 이의 대부분이 $[+2$ 일, +30 일]기간 동안에 발생하였음을 들어 시장 의 효율성에 의문을 제시하였다.

이와 같은 현상이 일반적인 것인가를 확인하기 위해 본 연구에서도 event date 시점뿐만 아니라 그 이후 $[+2$ 일, +60 일]기간 동안의 누적초과수익률을 각각 계산하였다. 이 경우 약 $5.5 \%$ 의 추가적인 주가상승이 있었으나, 통계적으로는 유의하지 않았다 (<표 2> 참조). 이는 송영균(1991)과는 달리 시장수익률 $R_{m, t}$ 의 측정치로 종합주가지수가 아닌 가치동일지수수익 률을 사용하는 등 방법론상의 차이에서 기인하는 것으로 파악된다. ${ }^{2}$ 따라서 event date 시점 에서 주가가 오르지 않고 이후 기간에 주가가 오르는 것을 투자자들의 지체된 반웅으로 보 는 것은 타당하지 않다.

<표 3>에는 가설 $2,3,4$ 를 테스트하기 위하여 실시한 중회귀분석 결과가 나와 있다.

<표 3> event date 시점에서의 중회귀분석 결과*

\begin{tabular}{|l|c|c|c|c|}
\hline 종속변수 & \multicolumn{5}{|c|}{ 독립변수 } \\
\hline CAR $_{[-1,0]}$ & 상수항 & $F I N$ & CONS & SALES \\
\hline 계수 & 0.0462 & -0.0871 & $\mathbf{0 . 0 7 1 5}$ & 0.0016 \\
\hline$p$-values & 0.33 & 0.05 & 0.08 & 0.88 \\
\hline
\end{tabular}

우선, 금융기관의 상호변경이 비금융기관의 상호변경보다 더 큰 초과수익률 변동을 초래 한다는 것이 확인되었다 $(F I N=-0.0871, p=0.05)$. 따라서 두 번째 가설은 지지되었다. 평균적 으로 event date 당시 금융기관 표본의 초과수익률은 비금용기관 표본의 초과수익률보다 $8.71 \%$ 낮음올 알 수 있다. 이는 투자자들이 서비스를 제공하는 금융기관들이 상호변경으로 인해 생기는 정의 브랜드 자산가치의 창출보다는 이를 창출하기 위한 비용 또는 구조조정에 따른 위험의 중가에 보다 더 무게를 두고 있다는 추론을 가능하게 한다. 이는 Horsky and Swyngedouw (1987)와 비교할 때 일관된 결과이다.

세 번째 가설은 소비재를 생산하는 기업의 상호변경으로 인한 초과수익률은 산업재를 생 산하는 기업의 상호변경으로 인한 초과수익률과 같지 않다는 것이었다. 이 가설은 $10 \%$ 수 준에서 지지되었다 $(C O N S=0.0715, p=0.08)$. 소비재 기업의 초과수익률이 더 높다는 것은 소 비재 시장에서보다 산업재 시장에서 브랜드의 영향력이 더 크기 때문이라고 해석된다.

네 번째 가설은 규모가 큰 기업의 초과수익률은 규모가 작은 기업의 초과수익률과 같지 않 다는 것이었다. <표 3>은 기업의 규모와 상호 변경으로 인한 초과수익률 간에는 유의한 관 계가 없다는 것을 보여준다 $(S A L E S=0.0016, p=0.88)$. 이 결과도 Horsky and Swyngedouw (1987)의 결과와 일치한다.

\section{5. 결론}

2 누적초과수익률을 계산합에 있어 가치동일지수수익률이 아닌 종합주가지수를 사용함으로 인해 생기는 편의(bias)에 대해서 김권중 外(1994) 둥에서 많이 지적되고 있다. 
본 연구에서는 1990년대 들어와서 국내의 많은 대기업들이 실시한 Corporate Identity Program (CIP)으로 인한 기업 이름의 변경이 기업의 이익 흐름에 미치는 영향을 event study method를 이용하여 실중적으로 분석하였다.

이론적으로, CIP의 일환으로 시행되는 기업 이름의 변경은 기업의 가치에 두 가지 상반된 효과를 가져온다고 할 수 있다. 먼저, 긍정적인 측면을 살펴보면, 체계적인 $\mathrm{CIP}$ 의 결과로 채택되는 새로운 기업 이름은 그 기업이 판매하는 제품에 대한 수요 합수를 상향 이동시키 는 효과를 가져올 것이다. 또, 단지 기업 이름을 바꾼다는 사실 자체만으로도 기업 내외의 이해 관계자들에게 앞으로 사업 구조 조정과 같은 바람직한 변화가 있을 것이라는 signal을 보내는 효과를 낳을 수 있기 때문에, 주식 시장에서 긍정적인 평가를 받을 가능성이 높다. 그러나, 지금까지 축적해 온 브랜드 자산의 상실, 기업 이름 변경 사실을 널리 알리기 위한 광고 비용, 각중 시설물 등의 교체비용 등이 크게 들어간다는 점, 그리고 모든 계열사들이 동일한 이름을 사용하기 때문에 그 중 어느 한 기업에 대한 부정적인 여론이 다른 모든 계 열사들에게까지 줗지 않은 영향올 미칠 수 있다는 위헙 등은 주가에 부정적인 영향올 미칠 가능성이 높다.

기업 이름의 변경이 기업의 이익 흐름에 미치는 영향을 event study method를 이용하여 실 중적으로 분석한 국내외의 연구들은 상반된 결과들을 보여주고 있다. 미국의 58 개 기업들 을 대상으로 한 연구에서 Horsky and Swyngedouw (1987)는 퉁계적으로 유의한 긍정적인 효과 를 발견한 반면, 국내의 74개 기업들올 대상으로 한 송영균 (1991)의 연구에서는 퉁계적으로 유의한 효과블 발견하지 못하였다. 본 연구는 기업 이름올 변경하게 되는 여러가지 동기 중에서 $\mathrm{CIP}$ 에 의한 변경에만 초점을 맞추었다는 점에서 기존의 연구들과 구별된다. 또, 최 초 공시일을 event date로 설정한 송영균 (1991)의 연구와는 달리, 최초 보도일과 최초 공시일 중에서 더 빠른 날을 event date로 설정함으로써, 분석의 정확성을 높이고자 하였다.

이와 같은 목적을 달성하기 위하여, 본 연구에서는 1992년부터 1996년 사이에 CIP의 일환 으로 기업 이름을 모기업 또는 그룹의 명칭과 동일하게 변경시킨 31 개 기업들을 대상으로 event study를 실시하였으며, 다음과 같은 결과를 얻을 수 있었다: 첫째, event date 하루 전과 event date 당일, 즉 [-1일, 0 일]의 기간 동안의 누적 평균 초과 수익률은 퉁계적으로 유의하지 않았다. 둘째, event date 이후 [+2일, +60 일] 기간 동안의 누적 초과 수익률 역시 상호 변경과 는 무관한 것으로 나타넜다. 셋째, 업종별로 분석해보면, 금융기관의 상호 변경이 비금융기 관의 상호 변경보다 퉁계적으로 더 낮은 초과수익률올 나타냈으며, 소비재를 생산하는 기업 들의 상호 변경은 산업재를 생산하는 기업들의 상호 변경보다 붕계적으로 더 높은 초과수익 률을 보였다. 결국, 평균적으로, 국내 주식 시장은 CIP로 인한 기업의 상호 변경에 대하여 호의적으로 반응하지 않지만, 비금윱기관과 소비재를 생산하는 기업들의 경우에는 호의적인 반응을 기대할 수 있다고 결론지을 수 있다. 이러한 연구 결과는 앞으로 CIP 실시를 고려 하는 기업들에게 많은 시사점을 던져주는 것이다.

본 연구의 범위를 보다 확대시켜서 event study를 해 보는 것은 의미있는 향후 과제가 될 것이다. 예를 들어, 92년 이전에 CIP로 인한 상호 변경을 실시한 기업들을 모두 분석 대상 에 포함시키거나, 더 나아가 CIP 이외의 사유로 상호를 변경한 기업들도 포함시킬 수 있을 것이다. 특히 후자의 경우, 충분한 표본 수가 학보된다면, 상호 변경의 사유별로 기업 가치 에 미치는 영향을 분석하는 것도 훙미로운 연구 과제가 될 것이다. 또, 충분한 수의 표본이 확보된다면, 기업의 규모별로 CIP의 효과를 검정해 볼 필요가 있을 것이다. 


\section{<참고문헌>}

김권중, 황선웅, 김진선 (1994), “지수수익률의 선택과 초과수익률 추정치의 편의”, 중견학혀지, 제 16 집.

송영균 (1991), “상호변경이 주주의 부에 미치는 영향에 관한 연구”, 중권학회지, 제13집, 67-101.

Bernard, V. and J. Thomas (1989), "Post-earnings Announcement Drift: Delayed Price Reaction Or Risk Premium?" Journal of Accounting Research, 27, 1-36. and _ (1990), "Evidence That Stock Prices Do Not fully Reflect The Implications Of

Current Earnings For Future Earnings" Journal of Accounting and Economics, 13, 305-340.

Briones, Maricris G. (1998), "When A Rose Is No Longer A Rose," Marketing News, April 13, 1-2.

Brown, S. J. and J. B. Warner (1980), "Measuring Security Price Performance," Journal of Financial Economics, 8, 205-258. and (1985), "Using Daily Stock Returns: The Case of Event Studies," Journal of

Financial Economics, 14, 3-31.

Fama, E. F. (1970), "Efficient Capital Markets: A Review Of Theory And Empirical Work," Journal of Finance, 25, 383-417.

Horsky, Dan and Patrick Swyngedouw (1987), "Does It Pay To Change Your Company's Name? A Stock Market Perspective," Marketing Science, Vol. 6, No. 4, Fall, 320-335.

Lakonishok, J. and T. Vermaelen (1990), "Anomalous Price Behavior Around Repurchase Tender Offers," Journal of Finance, 455-77. 